\title{
Grand Canonical Monte Carlo Modeling of Anesthetic Xe Separation from Exhale Gas Mixtures Using Metal Organic Frameworks
}

\author{
Yeliz GURDAL* \\ Department of Bioengineering, Adana Alparslan Turkes Science and Technology University, Turkey
}

Geliș / Received: 30/11/2019, Kabul / Accepted: 24/12/2019

\begin{abstract}
Xe has been shown to be a promising candidate for anesthetic applications. However, its high price prevents its usage in clinical industry. An alternative approach is to recover Xe from anesthetic exhale gas mixture and recycle it to the inhale gas stream. Although, many membranes and/or adsorbents have been proposed for recovering anesthetic Xe, using metal organic frameworks (MOFs) for adsorption based separation of anesthetic Xe exhale gas mixtures has been newly studied. MOFs have tunable pore sizes, large surface areas, and high porosities which make them potential candidates for gas separation applications. Currently, very little is known about anesthetic Xe recovery performances of MOFs. We theoretically investigate adsorption based separation of single component and binary mixtures of $\mathrm{CO}_{2}, \mathrm{Xe}$, and $\mathrm{N}_{2}$ in three MOFs, namely CECYOY, SUDBOI, and ZUQPOQ. Single component and binary adsorption isotherms and adsorption selectivities are calculated using Grand Canonical Monte Carlo simulations for each MOF in order to characterize their performances as adsorbents. Results suggest that while MOFs prefer adsorption of $\mathrm{CO}_{2}$ for $\mathrm{CO}_{2} / \mathrm{Xe}$ mixture, $\mathrm{Xe}$ adsorption is favorable in the case of $\mathrm{Xe} / \mathrm{N}_{2}$ mixture. While SUDBOI shows significantly large $\mathrm{CO}_{2}$ adsorption selectivity for $\mathrm{CO}_{2} / \mathrm{Xe}$ mixture, ZUQPOQ has the largest adsorption selectivity for $\mathrm{Xe} / \mathrm{N}_{2}$ mixture.
\end{abstract}

Keywords: Grand Canonical Monte Carlo simulations, metal organic frameworks, gas separation

Metal Organik Çerçeveler Kullanarak Ekshale Gaz Karışımlarından Anestezik Xe Ayrılmasının Grand Canonical Monte Carlo Yöntemi ile Modellenmesi

$\ddot{O ̈ z}$

Xe'nin anestezi uygulamalarında kullanılabileceği literatürdeki çalışmalarda gösterilmiştir. Fakat, yüksek maaliyeti Xe'nin klinik uygulamalarda kullanımını engellemektedir. Buna çözüm üretebilecek bir yaklaşım olarak, Xe'nin solunum yoluyla verilen anestezik gaz karışımından geri kazanılması ve solunan gaz akımına geri beslenmesi önerilmiştir. Anestetik Xe'nin geri kazanılması için birçok membran ve/veya adsorban önerilmiş olsa da, anestezik Xe'nin metal organik kafes yapılar (MOF) kullanılarak geri kazanılması yeni çalışılmaya başlanan bir konudur. MOF'ların gaz ayırma uygulamalarında kullanılmalarına olanak veren özellikleri ayarlanabilir gözenek boyutlarına, geniş yüzey alanlarına ve yüksek gözenekli yapıya sahip olmalarıdır. Literatürde MOF'ların anestezik Xe gazını geri kazanım performansları hakkında sınırlı sayıda çalışma vardır. Çalışmamızda CECYOY, SUDBOI, and ZUQPOQ isimli MOF'ların tek bileşenli ve ikili $\mathrm{CO}_{2}, \mathrm{Xe}$ ve $\mathrm{N}_{2}$ karışımlarını adsorpsiyon bazlı ayırma performansları incelenmiştir. Gazların tekli ve karışım halindeki adsorpsiyon izotermleri ve adsorpsiyon seçicilikleri her bir MOF için Grand Canonical Monte Carlo simülasyonları kullanılarak hesaplanmıştır. Sonuçlar, $\mathrm{MOF}$ 'larda $\mathrm{CO}_{2} / \mathrm{Xe}$ karışımı için $\mathrm{CO}_{2}$ adsorpsiyonunun tercih edildiğini, Xe adsorpsiyonunun ise $\mathrm{Xe} / \mathrm{N}_{2}$ karışımı durumunda tercih edildiğini göstermiştir. SUDBOI, $\mathrm{CO}_{2} / \mathrm{Xe}$ karışımı için yüksek $\mathrm{CO}_{2}$ adsorpsiyon seçiciliği gösterirken, ZUQPOQ, Xe/ $\mathrm{N}_{2}$ karışımı için en yüksek Xe adsorpsiyon seçiciliğine sahiptir.

Anahtar Kelimeler: Grand Canonical Monte Carlo Simülasyonu, metal oraganik kafes yapılar, gaz ayırma 


\section{Introduction}

Xenon (Xe), being a noble gas, has several usage in engineering applications including lighting, biomedical imaging, nuclear magnetic resonance, neutron counters (Banerjee et al., 2018). Additionally, Xe is shown to be a potential candidate for anesthetics applications. Xe has high chemical stability, low flammability, low solubility in blood, minimal respiratory side effects, low interactions with drug molecules, which makes it a perfect candidate to be used as an anesthetics (Neice and Zornow, 2016). It can bind to proteins such as myoglobins as well as bilayer lipids through temporary polarization of its electrons (Franks, 2008). Although, Xe is shown to be a promising candidate in anesthetics applications, currently its price is preventing itself from being used as an anesthetic gas. The price of high purity $\mathrm{Xe}$ is reported as $\$ 5000$ per kilogram (Elsaidi et al., 2017). This significantly high price arises from the cost of obtaining pure $\mathrm{Xe}$, through energetically intensive cryogenic distillation of air. For clinical purposes, though, Xe gas can be recovered from the anesthetic gas mixture and recycled back for further usage.

Some portable Xe recovery devices for clinical usage have been already proposed in the literature. One example is, liquefying Xe at high pressure, $66 \mathrm{bar}$, and separating it from the exhale gas mixture using soda lime (Georgieff and Bader, 1996). Another study proposes the use of activated carbon at $77 \mathrm{~K}$ and slowly boiling of Xe first by increasing the temperature the system (Burov et al., 2000). These methods require high energy and yield high capital and operation costs, thus preventing re-use of the Xe gas in the medical industry. Proposing cheap and highly efficient Xe recovery systems becomes important in the development of renewable applications.
Searching for alternative technologies for Xe recovery from anesthetic exhale gas is its infancy period in the literature, thus, deserves further detailed theoretical and/or experimental investigation.

Metal organic frameworks (MOFs) have been shown to be promising nanoporous material candidates for separating Xe from its binary mixtures of $\mathrm{Xe} / \mathrm{Kr}$ and $\mathrm{Xe} / \mathrm{Ar}$ (Gurdal and Keskin, 2016; Gurdal and Keskin 2013). The exceptional performances of MOFs for gas separation applications are attributed to their high surface area, high porosity, high chemical/physical stability, and wide range of pore size enabling selective separation of the gas mixtures (Gurdal and Keskin, 2012).

There are a few literature on the Xe recovery from anesthetic gas mixture using MOFs. Elsaidi et al. (2017) have conducted combined experimental and theoretical work to investigate $\mathrm{Xe}$ recovery from anesthetic exhale gas mixtures of $65 \% \mathrm{Xe}, 24 \% \mathrm{O}_{2}, 6 \%$ $\mathrm{N}_{2}$, and $5 \% \mathrm{CO}_{2}$ using MOFs (NiDOBDC, HKUST-1, and PCN-12). According to the results, NiDOBDC, HKUST-1, and PCN-12 have high Xe uptakes of 2.62, 3.62, and 4.4 $\mathrm{mmol} / \mathrm{g}$, respectively. Among the others, $\mathrm{PCN}-12$ also shows higher $\mathrm{Xe} / \mathrm{O}_{2}, \mathrm{Xe} / \mathrm{N}_{2}$, and $\mathrm{Xe} / \mathrm{CO}_{2}$ adsorption selectivity, which are calculated as 18.25, 18.46, and 1.99, respectively. Wang et al. (2019) have studied DD3R zeolite membranes for selective separation of $\mathrm{CO}_{2}$ from Xe by experimental and theoretical efforts. Results suggest that DD3R zeolite can be a benchmark membrane providing high diffusion selectivity of $\mathrm{CO}_{2}$ over Xe. Wang and Kapteijn et al. (2019) have investigated potential usage of MFI zeolite for $\mathrm{CO}_{2} / \mathrm{Xe}$ membrane-based separation. They show that MFI zeolite membrane favors $\mathrm{CO}_{2}$ permeation much higher than $\mathrm{Xe}$ which is attributed to facilitated diffusion of $\mathrm{CO}_{2}$ in 
short and straight channels of the b-oriented MFI.

To the best our our knowledge, there has been only three literature addressing recovery of the Xe from anesthetic exhale gas mixture using nanoporous materials. To fill this gap in the literature, our aim is to theoretically investigate adsorption based separation performances of single component and binary mixtures of $\mathrm{CO}_{2}, \mathrm{Xe}$, and $\mathrm{N}_{2}$ by taking advantage of MOFs, namely CECYOY, SUDBOI, and ZUQPOQ. Grand canonical Monte Carlo (GCMC) simulations are performed in order to determine adsorption of the gas mixtures in corresponding MOFs. In addition to calculating adsorption isotherms, we also calculate adsorption selectivities for determining potential MOFs that can recover $\mathrm{Xe}$ from the anesthetic gas mixture selectively and efficiently.

\section{Material and Methods}

We perform Grand Canonical Monte Carlo (GCMC) (Allen and Tildesley, 1987) simulations to compute adsorption isotherms of single and binary components of anesthetic exhale gas mixtures, such as $\mathrm{CO}_{2}, \mathrm{Xe}$, and $\mathrm{N}_{2}$ in MOFs having different pore sizes and porosities. We investigate the adsorption behavior of three MOFs, namely CECYOY, SUDBOI, and ZUQPOQ. Structural parameters of the MOFs under consideration are summarized in Table 1.
Table 1. Structural properties of the MOFs considered in this work. PLD and LCD stands for pore limiting diameter and largest cavity diameter, respectively. For more details, see Ref. [13].

\begin{tabular}{|c|c|c|c|c|c|}
\hline MOFs & $\begin{array}{c}\text { PLD } \\
(\AA)\end{array}$ & $\begin{array}{c}\text { LCD } \\
(\AA)\end{array}$ & $\begin{array}{c}\text { Porosity } \\
(\mathbf{\%})\end{array}$ & $\begin{array}{c}\text { Density } \\
\left(\mathbf{g} / \mathbf{c m}^{\mathbf{3}} \mathbf{)}\right.\end{array}$ & $\begin{array}{c}\text { Accessible } \\
\text { Surface } \\
\text { Area } \\
\left(\mathbf{m}^{2} / \mathbf{g}\right)\end{array}$ \\
\hline CECYOY & 3.34 & 3.85 & 38 & 1.67 & 26.48 \\
\hline SUDBOI & 3.6 & 6.29 & 56 & 1.23 & 599.8 \\
\hline ZUQPOQ & 3.41 & 4.02 & 33 & 1.53 & 122.49 \\
\hline
\end{tabular}

As it can be seen from the Table 1, SUDBOI has the largest pores with respect to CECYOY and ZUQPOQ. Accordingly, its accessible surface area is the largest one, $599.8 \mathrm{~m}^{2} / \mathrm{g}$. CECYOY, on the other hand, possesses the smallest PLD and LCD (Altintas and Keskin, 2017). While, SUDBOI has the largest porosity, 56\%, CECYOY and ZUQPOQ show similar porosities, being $38 \%$ and $33 \%$, respectively.

Atomic positions of the MOF crystals are taken from the Cambridge Crystallographic Data Centre (CCDC) (Allen, 2002). We assume rigid structures for the MOFs which have been tested and shown as an appropriate simulation strategy for most of the MOFs.

Lennard-Jones (LJ) potentials are used to calculate the gas-gas and gas-MOF atoms interactions (Frenkel and Smit, 1987). Lorentz-Berthelot mixing rules are used in order to calculate the $\mathrm{LJ}$ interactions of dissimilar atoms. Universal Force Field (UFF) parameters are employed throughout the simulations (Rappe et al., 1992). In the case of $\mathrm{CO}_{2}$ and $\mathrm{N}_{2}$, electrostatic interactions described via Coulomb's potential are also taken into account in addition to dispersion interactions. $\mathrm{CO}_{2}$ is modeled as a three-site rigid linear molecule with the charges located on each atom using EPM2 potential (Potoff and Siepmann, 2001). $\mathrm{N}_{2}$ molecule is defined 
with a three-site model with two sites located on two $\mathrm{N}$ atoms and one site is on the molecule's center of mass with partial point charges (Makrodimitris et al., 2001). Electrostatic charges on MOF atoms are reproduced from the study of Erucar et al. (2014) where charges of the MOF atoms are derived from density derived electrostatic and chemical (DDEC) method. Simulation results of the $\mathrm{CO}_{2}-\mathrm{MOF}$ systems using DDEC method has already shown to agree well with the experimental results (Erucar et al., 2014). While cut-off distance is set as $13 \AA$ for the $\mathrm{LJ}$ interactions, $25 \AA$ is used for the electrostatic interactions. Periodic boundary conditions are always applied.

$2 \times 2 \times 2$ replica of the unit cell is used as a simulation box. $3 \times 10^{7}$ trial configurations are used in the GCMC simulations in total, where half of the moves are considered as equilibration, thus the other half is used for the data collection. In single component GCMC simulations, a move is defined as translation, creation/deletion, and rotation (in the case of $\mathrm{CO}_{2}$ and $\mathrm{N}_{2}$ ) of the particles. In the case of mixture simulations, on the other hand, an additional move of exchange of the particles are also attempted.

A good indication of the promising adsorbent materials is their high selectivity towards a gas specie. The adsorption selectivity is calculated using the equation below:

$S_{a d s}(i / j)=x_{i} / x_{j} y_{i} / y_{j}$

here $\mathrm{x}$ and $\mathrm{y}$ are the molar fractions of the adsorbed and gas phases of the species, respectively. For the mixture adsorption simulations $\mathrm{CO}_{2} / \mathrm{Xe}$ and $\mathrm{Xe} / \mathrm{N}_{2}$ mixture compositions are set to $20 / 80$ and $80 / 20$, respectively.

\section{Results and Discussion}

Single component and mixture adsorption isotherms of $\mathrm{CO}_{2}$ and $\mathrm{Xe}$ species as a function of bulk pressure at $298 \mathrm{~K}$ in considered MOFs are depicted in Figure 1. As a first observation, although in CECYOY and SUDBOI single component $\mathrm{CO}_{2}$ adsorption is higher than the one observed for single component $\mathrm{Xe}$, in ZUQPOQ pores of the nanoporous material attract $\mathrm{CO}_{2}$ and $\mathrm{Xe}$ gas species as a similar manner leading similar adsorption amount for both gas species. At 10 bar of feed pressure, single component $\mathrm{CO}_{2}$ adsorption data of CECYOY, SUDBOI, and ZUQPOQ are calculated as 10.90, 13.50, and 4 molecules/unitcell, respectively. Single component Xe uptake at 10 bar, on the other hand, are calculated as 8.45, 5.54, and 3.94 molecules/unitcell in CECYOY, SUDBOI, and ZUQPOQ, respectively. The gap between single component uptakes of $\mathrm{CO}_{2}$ and $\mathrm{Xe}$ is more pronounced in the case of SUDBOI, where saturated $\mathrm{CO}_{2}$ and $\mathrm{Xe}$ uptakes are 14.60 and 6.20 molecules/unitcell, respectively. While CECYOY and SUDBOI reach saturation of adsorption of the single component species at around 25 bar, in the case of ZUQPOQ $\mathrm{CO}_{2}$ and $\mathrm{Xe}$ gas species reach saturation point at a lower pressure, around 4 bar.

Mixture gas adsorption simulation results reveal that both $\mathrm{CO}_{2}$ and $\mathrm{Xe}$ adsorption are affected from each due to filling of the available adsorption sites by dissimilar specie. While $\mathrm{CO}_{2}$ is interacting with the $\mathrm{MOF}$ adsorbents through electrostatic and dispersion interactions, its only dispersion type interaction in the case of Xe. Due to this reason, we observe that $\mathrm{Xe}$ adsorption is always suppressed by $\mathrm{CO}_{2}$ adsorption for $\mathrm{CO}_{2} / \mathrm{Xe}: 20 / 80$ mixture in considered MOFs. 
We observe a sharp decrease in the $\mathrm{CO}_{2}$ uptakes of the MOFs in the mixture case with respect to its single component adsorption amount. However, this decrease is less pronounced in the case of CECYOY, where at 10 bar mixture $\mathrm{CO}_{2}$ adsorption amount is decreased to 6.60 molecules/unitcell. We observe even more significant decrease in the Xe adsorption amount for the case of mixture gas simulations in all considered MOFs. At 10 bar calculated $\mathrm{Xe}$ uptake values for the $\mathrm{CO}_{2} / \mathrm{Xe}: 20 / 80$ mixture are $3.34,0.36$, and 1.30 molecules/unitcell in CECYOY, SUDBOI, and ZUQPOQ, respectively.

The significant decrease in the mixture $\mathrm{Xe}$ adsorption isotherms are attributed to the attractive electrostatic interactions between $\mathrm{CO}_{2}$ and the MOF atoms resulting in occupation of the adsorption sites by the $\mathrm{CO}_{2}$ molecules. Prevention of the Xe adsorption is more pronounced in the CECYOY and SUDBOI with respect to ZUQPOQ. We observe competition between electrostatic and dispersion interactions. Combination of electrostatic and dispersion interactions between $\mathrm{CO}_{2}$ and $\mathrm{MOF}$ atoms outperform mixture $\mathrm{Xe}$ adsorption in the pores, yielding adsorption based separation of $\mathrm{CO}_{2} / \mathrm{Xe}$ mixture.

$\mathrm{N}_{2}$ and $\mathrm{Xe}$ mixture adsorption isotherm calculations are carried out using 20\% and $80 \%$ composition of $\mathrm{N}_{2}$ and $\mathrm{Xe}$ gases, respectively. Corresponding GCMC results are shown in Figure 2. (a)
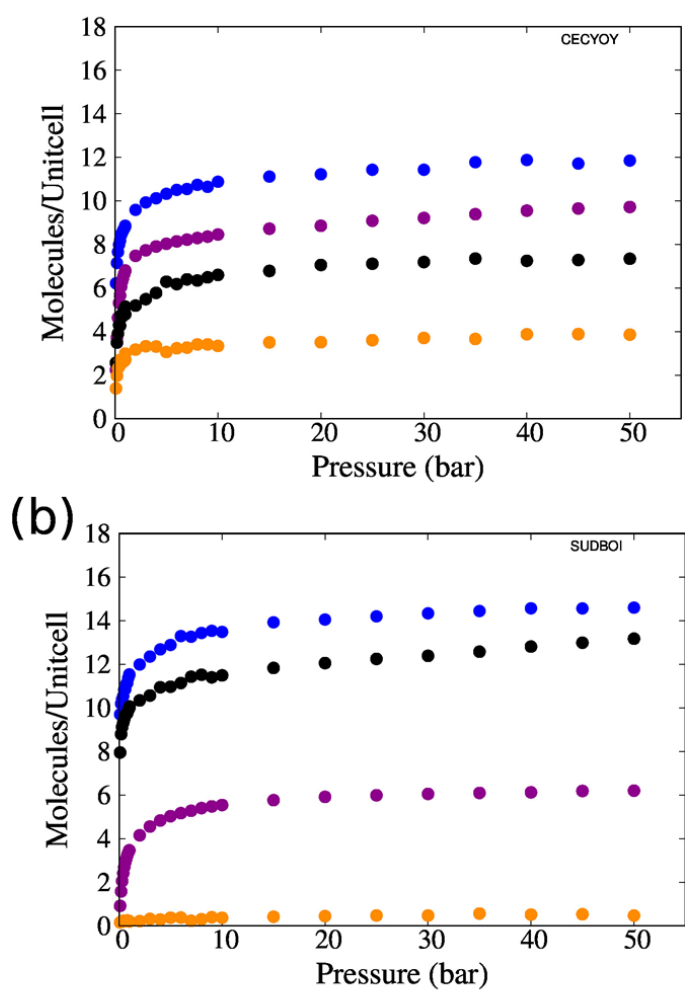

(c)

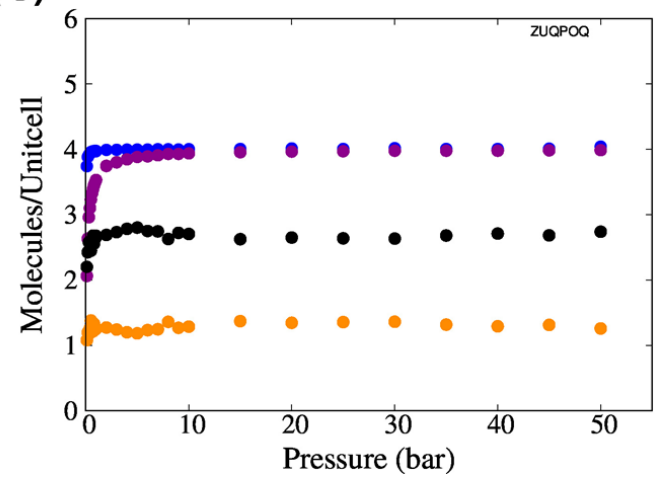

Figure 1. Single specie and mixture uptake data of $\mathrm{CO}_{2} / \mathrm{Xe}$ in (a) CECYOY, (b)SUDBOI, and (c) ZUQPOQ carried out at $298 \mathrm{~K}$. Xe and $\mathrm{CO}_{2}$ compositions of the feed gas is set to $80 \%$ and $20 \%$, respectively. Blue circles represent single component $\mathrm{CO}_{2}$ uptake, purple ones depict single component Xe uptake, black circles show $\mathrm{CO}_{2}$ uptake in the mixture, and orange ones depict $\mathrm{Xe}$ uptake in the $\mathrm{CO}_{2} / \mathrm{Xe}: 20 / 80$ mixture.

As a general observation, for the single component gas specie adsorption, while Xe adsorption reaches saturation in the MOF pores at smaller pressure values, around 4 bar, in the case of $\mathrm{N}_{2}$ adsorption, we observe 
saturation at significantly high pressures, around 50 bar, for all the considered MOFs. Xe uptake of MOFs increases steeply at early pressure values.

$\mathrm{Xe} / \mathrm{N}_{2}: 80 / 20$ mixture adsorption calculations reveal that, dispersion interactions between $\mathrm{Xe}$ and $\mathrm{MOF}$ atoms outperform $\mathrm{N}_{2}$ adsorption in the pores. MOF pores are filled by $\mathrm{Xe}$ atoms, and negligibly low amount of $\mathrm{N}_{2}$ molecules can find place on the adsorption sites. As it can be seen from Figure 2, while there is almost negligible change between the values of single component and mixture $\mathrm{Xe}$ adsorption, a sharp decrease is observed in the case of mixture $\mathrm{N}_{2}$ with respect to its single component adsorption values.

In fact, $\mathrm{N}_{2}$ adsorption is almost blocked by the $\mathrm{Xe}$ atoms in all the MOFs under consideration. Preferable adsorption of $\mathrm{Xe}$ atoms over $\mathrm{N}_{2}$ have been also observed in the literature in other MOFs. For instance, Panter and Zarabadi-Poo (2018) studied Xe separation from air in several IRMOF materials and results always indicate selective adsorption of Xe over $\mathrm{N}_{2}$ molecules. Zhong et al. (2016) investigated the $\mathrm{Xe} / \mathrm{N}_{2}$ adsorptionbased separation of adsorption performance of nitrogen-doped porous Carbon material which shows exceptional Xe uptake over $\mathrm{N}_{2}$.

Mixture $\mathrm{N}_{2}$ adsorption preference of the considered MOFs shows the opposite behavior with respect to the mixture $\mathrm{CO}_{2}$ adsorption considering preferable $\mathrm{CO}_{2}$ adsorption in the MOFs. As in the case of $\mathrm{CO}_{2}, \mathrm{~N}_{2}$ molecules are also interacting through electrostatic and dispersion interactions with the MOF pores. (a)

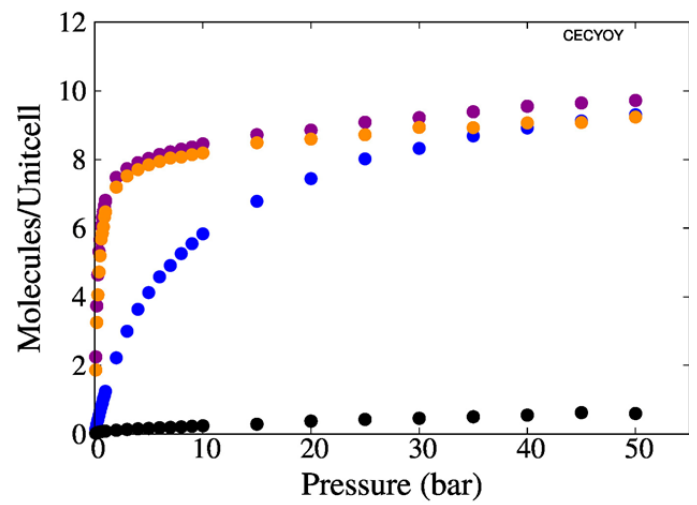

(b)

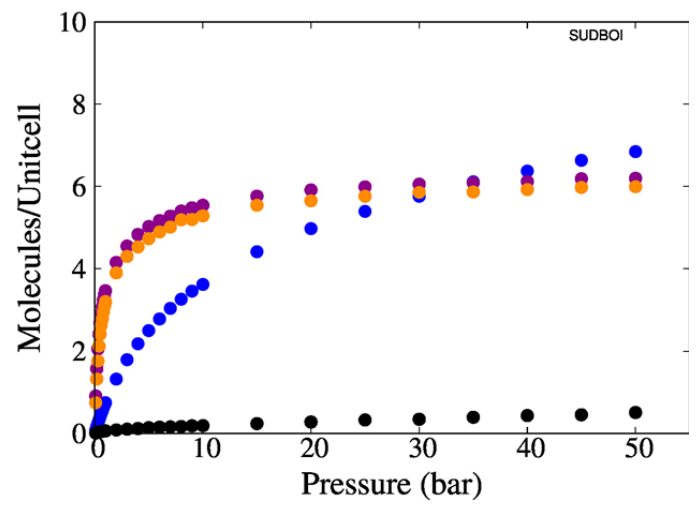

(c)

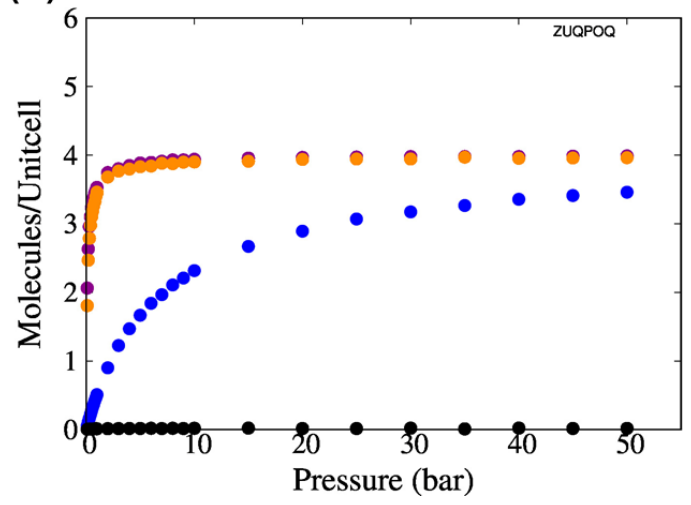

Figure 2. Single specie and mixture uptake data of $\mathrm{Xe} / \mathrm{N}_{2}$ in (a) CECYOY, (b)SUDBOI, and (c) ZUQPOQ carried out at $298 \mathrm{~K}$. Xe and $\mathrm{N}_{2}$ compositions of the feed gas is set to $80 \%$ and $20 \%$, respectively. Blue circles represent single component $\mathrm{N}_{2}$ uptake, purple ones depict single component Xe uptake, black circles show $\mathrm{N}_{2}$ uptake in the mixture, and orange ones depict $\mathrm{Xe}$ uptake in the $\mathrm{Xe} / \mathrm{N}_{2}: 20 / 80$ mixture. 
To investigate the effects of electrostatics on the adsorption of mixture $\mathrm{CO}_{2}$ and mixture $\mathrm{N}_{2}$ species, we carry out GCMC analysis using CECYOY by turning-off electrostatic interactions. Figure 3 shows the adsorption isotherms of $\mathrm{CO}_{2}$ and $\mathrm{N}_{2}$ by turning on and off electrostatic interactions for $\mathrm{CO}_{2} / \mathrm{Xe}$ and $\mathrm{Xe} / \mathrm{N}_{2}$ mixtures. As it can be seen from Figure 3 , turning-off electrostatic interactions has insignificant effect on both mixture $\mathrm{CO}_{2}$ and mixture $\mathrm{N}_{2}$ adsorption amounts. This result suggest that dispersion type interaction is the key factor determining adsorption isotherms. Electrostatic interactions having small effect in modeling gas-MOF systems have been also discussed in the study of Erucar et al. [19], where turning-off electrostatics in modeling $\mathrm{CO}_{2} / \mathrm{CH}_{4}, \mathrm{CO}_{2} / \mathrm{N}_{2}$, and $\mathrm{H}_{2} / \mathrm{CO}_{2}$ adsorption and diffusion in MOFs can give similar results with the electrostatics-on scenario.

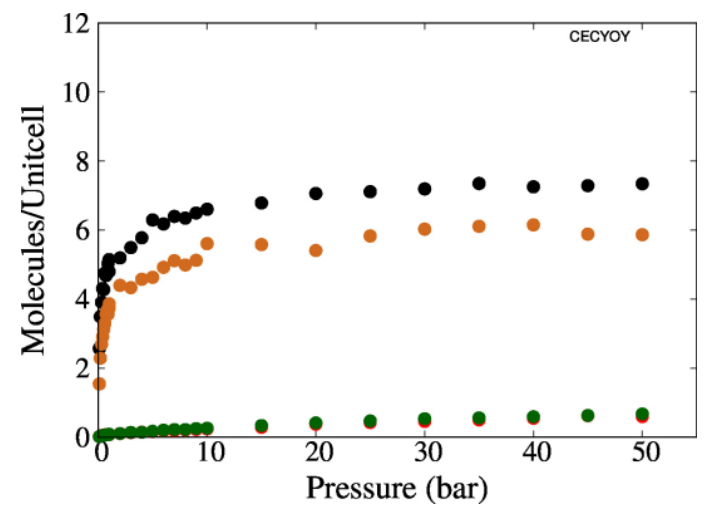

Figure 3. Effects of electrostatic interactions on mixture $\mathrm{CO}_{2}$ and $\mathrm{N}_{2}$ adsorption isotherms calculated for CECYOY. While black (brown) circles show electrostatic interactions on (off) calculations for $\mathrm{CO}_{2}$, red (green) shows electrostatics on (off) calculations for $\mathrm{N}_{2}$.

As it is clear from Figure 3, dispersion type interactions are playing determining role in mixture $\mathrm{Xe}$ and $\mathrm{N}_{2}$ adsorption of considered MOFs. Energy force field parameters of the $\mathrm{CO}_{2}$ and $\mathrm{Xe}$ are much higher than the one for $\mathrm{N}_{2}$ which explains preferable adsorption of $\mathrm{CO}_{2}$ or Xe adsorption over $\mathrm{N}_{2}$. Considering larger adsorption of $\mathrm{CO}_{2}$ with respect to $\mathrm{Xe}$ is, instead, related with the steric hindrance affects. Van der Waals size of the Xe atom is larger than the one used for $\mathrm{CO}_{2}$, which prevents further adsorption of $\mathrm{Xe}$ atom in the MOF pores.

The adsorption based separation performances of the considered MOF materials are further investigated by calculating their adsorption selectivities with respect to feed gas pressure, see Figure 4. While for the $\mathrm{CO}_{2} / \mathrm{Xe}: 20 / 80$ mixture $\mathrm{CO}_{2}$ is the mostly adsorbed specie, in the case of $\mathrm{Xe} / \mathrm{N}_{2}: 80 / 20 \mathrm{Xe}$ adsorption is preferable. Thus, $\mathrm{CO}_{2}$ and $\mathrm{Xe}$ adsorption selectivities of the MOFs are calculated for $\mathrm{CO}_{2} / \mathrm{Xe}$ and $\mathrm{Xe} / \mathrm{N}_{2}$ mixtures, respectively.

As it can be seen from Figure 4(a), SUDBOI shows the highest $\mathrm{CO}_{2}$ adsorption selectivity among the other MOFs. At 0.1 bar $\mathrm{CO}_{2}$ adsorption selectivity is calculated as 205 , and as pressure increases selectivity decreases to 110 in SUDBOI. In the case of CECYOY and ZUQPOQ, on the other hand, selectivity values are around 10 and we observe negligible change in the selectivities as the pressure increases.

For the $\mathrm{Xe} / \mathrm{N}_{2}: 20 / 80$ mixture, see Figure 4(b), ZUQPOQ shows the largest Xe selectivity, where at 0.1 bar Xe selectivity is calculated as 68 and as pressure increases it decreases to 55. Xe selectivity values of CECYOY and SUDBOI are similar to each other, and at higher pressures Xe selectivities are decreased to 5 for both MOFs. 
(a)

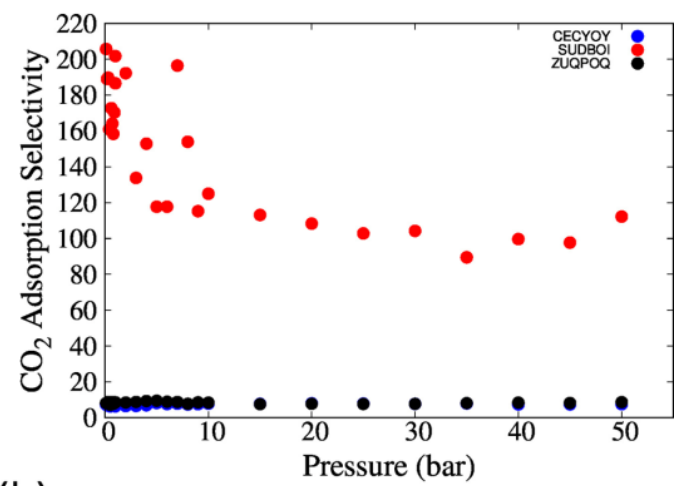

(b)

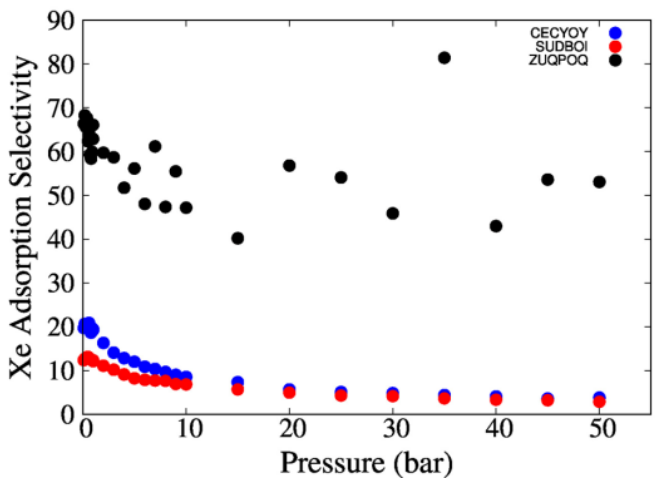

Figure 4. (a) $\mathrm{CO}_{2}$ and (b) $\mathrm{Xe}$ adsorption selectivity with respect to feed pressure for $\mathrm{CO}_{2} / \mathrm{Xe}$ and $\mathrm{Xe} / \mathrm{N}_{2}$ mixtures, respectively. Selectivity values calculated for CECYOY, SUDBOI, and ZUQPOQ are depicted using blue, red, and black circles, respectively.

\section{Conclusion}

We theoretically investigate adsorption-based anesthetic Xe recovery from the exhale gas for clinical industry by taking advantage of MOFs. We perform GCMC simulations to calculate adsorption isotherms of single component and binary mixtures of $\mathrm{CO}_{2}, \mathrm{Xe}$, and $\mathrm{N}_{2}$. To mimic the anesthetic exhale gas composition, we determine the gas mixture compositions as $\mathrm{CO}_{2} / \mathrm{Xe}: 20 / 80$ and $\mathrm{Xe} / \mathrm{N}_{2}: 80 / 20$. Equilibrium adsorption amounts of the gas species and adsorption selectivities are determined for the MOFs, namely CECYOY, SUDBOI, and ZUQPOQ. Results reveal that while more $\mathrm{CO}_{2}$ adsorption is preferred for the $\mathrm{CO}_{2} / \mathrm{Xe}$ mixture, $\mathrm{Xe}$ adsorption is more facilitated for the $\mathrm{Xe} / \mathrm{N}_{2}$ mixture in the considered MOFs. These results are attributed to the higher energy parameter of the Xe atom with respect to $\mathrm{N}_{2}$ which leads to enhanced dispersion type interactions between $\mathrm{MOF}$ pores and $\mathrm{Xe}$ atoms, thus preference of Xe adsorption over $\mathrm{N}_{2}$. In the case of $\mathrm{CO}_{2} / \mathrm{Xe}$ mixture, on the other hand, size parameter of $\mathrm{CO}_{2}$ is smaller than Xe. Thus, $\mathrm{CO}_{2}$ molecules fill the pores easier than Xe atoms which are prevented due to steric hindrance effects.

Adsorption selectivity calculations reveal that while SUDBOI shows significantly large $\mathrm{CO}_{2}$ adsorption selectivity for $\mathrm{CO}_{2} / \mathrm{Xe}, \mathrm{ZUQPOQ}$ has the largest Xe selectivity for the Xe/N2 mixture.

Our results suggest that while SUDBOI is ideal candidate for $\mathrm{CO}_{2}$ separation from $\mathrm{CO}_{2} / \mathrm{Xe}$, ZUQPOQ can be considered as promising candidate for Xe separation from $\mathrm{Xe} / \mathrm{N}_{2}$ mixture. However, $\mathrm{Xe}$ recovery scenarios are different in these MOFs, since SUDBOI separates $\mathrm{Xe}$ by facilitated $\mathrm{CO}_{2}$ adsorption over Xe, and ZUQPOQ separates Xe by facilitated Xe adsorption over $\mathrm{N}_{2}$. Thus, two step procedure for recovering anesthetic $\mathrm{Xe}$ can be proposed, such as firstly $\mathrm{CO}_{2}$ can be separated from the exhale gas mixture by $\mathrm{CO}_{2}$ adsorption in SUDBOI, then $\mathrm{Xe} / \mathrm{N}_{2}$ gas mixture can be separated by Xe adsorption in ZUQPOQ in the second step.

Our research can proceed in many directions. We simulate the adsorption based separation of binary anesthetic gas mixtures. Thus, simulating ternary mixtures of $\mathrm{CO}_{2} / \mathrm{Xe} / \mathrm{N}_{2}$ is highly motivated. Besides, it is known that an extent of $\mathrm{H}_{2} \mathrm{O}$ and $\mathrm{O}_{2}$ are also present in the anesthetic exhale gas mixtures. The effects of all these gas species on $\mathrm{Xe}$ recovery 
performances of MOFs are open questions that should be addressed. The results of this study with the possible extensions can provide a cheaper solution for Xe recovery in the clinical industry using the advantages of MOFs.

\section{Acknowledgments}

The numerical calculations reported in this paper were fully performed at TUBITAK ULAKBIM, High Performance and Grid Computing Center (TRUBA resources), located in Turkey.

\section{References}

Allen, F. H. 2002. "The Cambridge Structural Database: a quarter of a million crystal structures and rising", Acta Crystallographica Section B-Structural Science, 58(1), 380-388.

Allen, M., Tildesley, J., (1987). "Computer Simulations of Liquids," Oxford Science Publications, Oxford.

Altintas, C., Keskin, S. 2017. "Molecular simulations of MOF membranes for separation of ethane/ethene and ethane/methane mixtures", RSC Advances, 7, 52283-52295.

Banerjee, D., Simon, C. M., Elsaidi, S. K., Haranczyk, M., Thallapally, P. K. 2018. "Xenon Gas Separation and Storage Using Metal-Organic Frameworks", Chem, 4(3), 466-494.

Burov, V. P. N., Efimov, V., Makeev, G., Surnin, A., Vovk, S., (2000). "Method and Device for Regenerating Xenon from Narcotic Gas Mixture Used in Anesthesia Apparatus”. RU Patent No: 2149033.

Elsaidi, E., Ongari, D., Xu, W., Mohamed, M.H., Haranczyk, M., Thallapally, P. K. 2017. "Xenon Recovery at Room Temperature using Metal-Organic Frameworks", Chemistry-A European Journal Communication, 23, 10758 - 10762.
Erucar, I., Manz, T. A., Keskin, S. 2014. "Effects of electrostatic interactions on gas adsorption and permeability of MOF membranes", Molecular Simulation, 40 (7-9), 557-570.

Franks, N. P. 2008. "General Anaesthesia: From Molecular Targets to Neuronal Pathways of Sleep and Arousal", Nature Reviews Neuroscience, 9, 370-386.

Frenkel, D., Smit, B.,(1987). "Understanding Molecular Simulation: From Algorithms to Applications", Academic Press, San Diego.

Georgieff, T. M. M, Bader, S., (1996). "Anesthesia Arrangement for Recovering Gaseous Anesthetic Agents". US Patent No: 5, 520,169. May 28.

Gurdal, Y., Keskin, S. 2012. "Atomically Detailed Modeling of Metal Organic Frameworks for Adsorption, Diffusion, and Separation of Noble Gas Mixtures," Industrial \& Engineering Chemistry Research, 51(21), 7373-7382.

Gurdal, Y., Keskin, S. 2013. "Predicting Noble Gas Separation Performance of Metal Organic Frameworks Using Theoretical Correlations", The Journal of Physical Chemistry C, 117 (10), 5229-5241.

Gurdal, Y., Keskin, S. 2016. "A New Approach for Predicting Gas Separation Performances of MOF Membranes", Journal of Membrane Science, 519, 45-54.

Makrodimitris, K., Papadopoulos, G. K. , Theodorou, D. N. 2001. "Prediction of Permeation Properties of $\mathrm{CO}_{2}$ and $\mathrm{N}_{2}$ through Silicalite via Molecular Simulations", Journal of Physical Chemistry B, 105, 777- 788.

Neice, A. E., Zornow, M. H. 2016. "Xenon anesthesia for all, or only a select few?", Anaesthesia, 71(11), 1267-1272.

Panter, S., Zarabadi-Poo, P. 2018. "Computational Exploration of IRMOFs for Xenon Separation from Air", ACS Omega, 3(12), 18535-18541.

Potoff, J. J., Siepmann, J. I. 2001. "Vapor-Liquid Equilibria of Mixtures 
Containing Alkanes, Carbon Dioxide, and Xe Recovery", ACS Applied Materials and Nitrogen", AIChE Journal, 47, 1676-1682.

Interfaces, 10 (39), 33574-33580.

Rappe, A. K., Casewit, C. J., Colwell, K. S. , Wang, X., Zhang, Y., Wang, X., AndresGoddard, W. A., Skiff, W. M. 1992. "UFF, A full Periodic Table Force Field for Molecular Garcia, E., Du., P., Giordano, L., Wang, L., Hong, Z., Gu, X., Murad, S., Kapteijn, F. Mechanics and Molecular Dynamics Simulations", Journal of the American Chemical Society, 114(25), 10024-10035. 2019. "Xenon Recovery by DD3R Zeolite Membranes: Application in Anaesthetics", Angewandte Chemie International Edition,

Wang, X., Karakiliç, P., Liu, X., Shan, M., Nijmeijer, A., Winnubst, L., Gascon, J., Kapteij, F. 2018. "One-Pot Synthesis of HighFluxb-Oriented MFI Zeolite Membranes for 131, $15664-15671$.

Zhong, S., Wang, Q., Cao, D. 2016. “ZIFDerived Nitrogen-Doped Porous Carbons for Xe Adsorption and Separation", Science Reports, 21295-21306. 